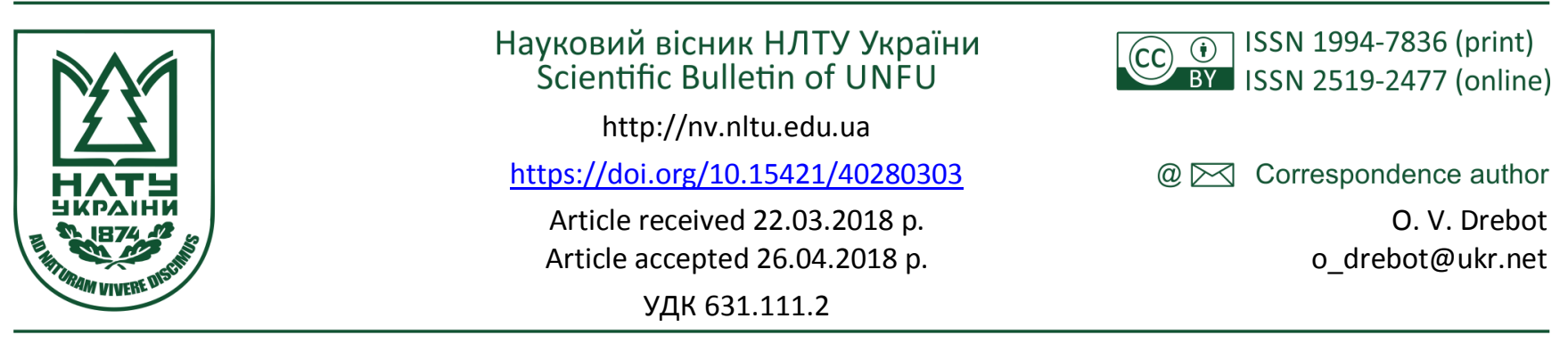

О. В. Дребот, А. П. Кудрик, А. О. Піціль, О. П. Лук'яненко

Житомирський національний агроекологічний університет, м. Житомир, Украйна

\title{
ПІДВИЩЕННЯ БІОРІЗНОМАНІТТЯ РОСЛИННИХ ФОРМАЦІЙ ПІД ЧАС ЗЕМЛЕУСТРОЮ АГРОЛАНДШАФТУ
}

\begin{abstract}
Проаналізовано сучасні світові літературні джерела, що висвітлюють питання підвищення біорізноманіття агроландшафтів. Встановлено, що питання $\epsilon$ актуальним, оскільки підтримання різноманітності видів живих елементів екосистеми $\epsilon$ обов'язковим для формування стійких територій. Зроблено висновок, що світові дослідження доводять - відновлення стійкості агроекосистем шляхом зменшення розораності території та збільшення біорізноманіття веде до пом'якшення наслідків зміни клімату шляхом створення агроландшафтів, близьких до природних. Дослідження проведено на площі землекористування в межах Великохайчанської сільської ради Овруцького району Житомирської області, що розташована на території Словечансько-Овруцького кряжу. Встановлено, що досліджувана територія різноманітна за рельєфом, грунтовим покривом та рівнем перезволоження. Під час формування травосумішей для залуження схилів враховано ступінь еродованості грунтів та біологічні особливості рослин. Під час облаштування сіножаті враховано чутливість рослин до зростання на перезволожених або заболочених територіях. На основі зіставлення агроекологічних властивостей грунтового покриву і біологічних особливостей багаторічних трав встановлено, що для сірих та ясно-сірих опідзолених грунтів досліджуваного агроландшафту найпридатнішою є травосуміш, в якій питома вага багаторічних трав для залуження схилів становить: бобових $25 \%$, злакових $-75 \%$. Для створення сіножаті на глейових грунтах відповідно - 15 і $85 \%$.
\end{abstract}

Ключові слова: землеустрій; сільськогосподарські угіддя; біорізноманіття; залуження схилів; травосуміші.

Вступ. Головна роль в оптимізації агроландшафту у безперервному самовідновленні та саморегуляції, що і забезпечус ренатуралізацію самих ландшафтів. Зональна різноманітність, розвиток травостою рослинних угруповань, їхня задернованість істотно впливають на поверхневий стік. У полідомінантних фітоценозах він значно менший, ніж у монодомінантних. Тому одним з ефективних заходів збереження грунту є фітомеліорація. Рослинність визначає структуру горизонтальної і вертикальної диференціації агроландшатного покриву та його функціонування внаслідок життєдіяльності біотично пов'язаних між собою природних польових і кормових фітоценозів. Біорізноманітність штучних та природних ценозів дає змогу зробити їх стійкими, продуктивними та якісними (Xutong, Shuai, \& Bojie, 2018). Ренатуралізація виведених з обробітку земель, передбачає створення на них рослинних угруповань, близьких до природних. Успіх цих заходів залежить насамперед від біорізноманіття організованих фітоценозів, які захищають грунт від ерозії і забезпечують сталість агроландшафту (Wei, Behzad, \& Yakai, 2018; Geijzendorffer, Cohen-Shacham, \& Cord, 2017; Lohbeck, Winowiecki, \& Aynekulu, 2018; Toderi, Francioni, \& Seddaiu, 2017). Теоретичні підходи до створення таких формацій з високою продуктивністю і максимальною стійкістю грунтуються на вивченні взаємодії рослин із середовищем їх життєвого простору, ïx екологічних особливостей та взаємодії між собою. Максимальної продуктивності фітоценозу досягають за відповідності агроекологічних властивостей грунтів вимогам рослин. Важлива роль у відновленні біорізноманіття належить землеустрою. Особливу увагу при цьому приділяють формуванню меж угідь та вибору напряму господарської діяльності (Chaplin-Kramer, Sim, \& Hamel, 2017; Durand, Desilles, \& Saint-Pierre, 2017; Nanni, Grau, 2017). Сьогодні проблеми збереження видів живих організмів, розширення площ антропогенних ландшафтів, вирубування лісів тісно пов'язують зі змінами клімату (Meadows, Herbohn, \& Emtage, 2018; Sidibe, Foudi, \& Pascual, 2018). Вчені стверджують, що землеустрій сільськогосподарських угідь має враховувати принципи формування агроландшафтів з максимальним наближенням до природних територій (Lima, Enoch, de Gois, \& Avelar, 2017; Yingjie, Liwei, \& Junping, 2017; Varela, Verheyen, \& Valdes, 2018; Xutong, Shuai, \& Bojie, 2018). Цiкавою $€$ думка, наприклад, щодо смугових посівів деревної рослинності та посівів сільськогосподарських культур (Gomez, Campos, \& Guzman, 2016; Wolz, Lovell, \& Branham, 2018).

\section{Інформація про авторів:}

Дребот Оксана Володимирівна, канд. с.-г. наук, в.о. завідувача кафедри геодезії та землеустрою. Email: o_drebot@ukr.net Кудрик Анатолій Порфирович, канд. с.-г. наук, доцент, кафедра геодезії та землеустрою. Email: zem_kudryk@ukr.net Піціль Андрій Орестович, ст. викладач, кафедра геодезії та землеустрою. Email: pitsil@ukr.net Лукяненко Олексій Петрович, асистент, кафедра геодезії та землеустрою. Email: oleksiy2014@meta.ua

Цитування за ДСТУ: Дребот О. В., Кудрик А. П., Піціль А. О., Лук'яненко О. П. Підвищення біорізноманіття рослинних формацій під час землеустрою агроландшафту. Науковий вісник НлТУ України. 2018, т. 28, № 3. С. 18-21.

Citation APA: Drebot, O. V., Kudryk, A. P., Pitsil, O. V., \& Lukianenko, O. P. (2018). Increasing Plant Formation Biodiversity During Agricultural Landscape Management. Scientific Bulletin of UNFU, 28(3), 18-21. https://doi.org/10.15421/40280303 
Матеріал і методи дослідження. Дослідження проводили на площі землекористування в межах Великохайчанської сільської ради Овруцького району Житомирської обл., що розташована на території Словечансько-Овруцького кряжу. Площа досліджуваної території - 2590,7 га, з них 1737,8 га зайнято сільськогосподарськими угіддями, лісом - 852,9 га. У північній і центральній частині землекористування $\epsilon$ ділянки з ухилами до $11^{\circ}$. Загальна площа еродованих земель 765,7 га. Грунтовий покрив цієї території представлений сірими опідзоленими грунтами різного ступеня еродованості. Південну частину агроландшафту займає слабохвиляста рівнина, де сформувались делювіальні наноси карбонатні глейові, дерново-слабопідзолисті глейові, дернові глибокі карбонатні глейові, та невеликими ділянками болотні і торфово-болотні грунти. Площа перезволожених і заболочених грунтів становить 365,8 га.

Напрями підвищення біорізноманіття у сучасних агроландшафтах вивчали за даними світових літературних джерел. Агроекологічний стан грунтового покриву досліджуваної території проаналізовано за ступенем еродованості грунту та ступенем перезволоження. Для цього використано вихідні картографічні дані: грунтова карта, картограма крутизни схилів, картограма рівня залягання грунтових вод, план організації території угідь. Під час формування травосумішей для залуження схилів враховано агроекологічний стан грунтів та біологічні особливості рослин щодо розгалуження кореневої системи, проекційного покриття поверхні грунту надземною масою рослин, термінів відростання навесні. Під час облаштування сіножаті враховано чутливість рослин до зростання на перезволожених або заболочених територіях. Під час створення рослинних угруповань також взято до уваги алелопатичні властивості рослин.

Результати дослідження. Одним з етапів збільшення біорізноманіття в агроландшафтах $\epsilon$ відновлення природних кормових угідь на землях, виведених з ріллі. Цей процес може відбуватися двома шляхами: самозаростанням або створенням штучних лучних ценозів. Під час самозаростання рослинні угруповання проходять закономірні послідовні стадії заміни польової рослинності на лучну. Внаслідок цього створюється ценоз, близький до природного, в якому понад $80 \%$ займають злаки, 10-15 - бобові рослини, 5-10 - різнотрав'я. Заселення грунту лучною рослинністю йде дуже повільно. Понад 10 років потрібно для створення в такий спосіб стійкого, здатного до саморегуляції, ценозу. Швидший шлях відтворення кормових угідь передбачає інтенсивне антропогенне втручання, внаслідок якого формуються високопродуктивні (300-400 ц/га зеленої маси) фітоценози. Вирішальне значення в цьому процесі має підбір трав для сумішей. Ренатуралізація схилів у разі залуження їх злаково-бобовими сумішами відбувається впродовж 4-8 років (Tarariko \& Moskalenko, 2002; Sharashova, 1989).

На основі вивчення літературних джерел щодо сумісності посівів різних видів трав, їх біологічних особливостей щодо вимог до умов вирощування та 3 урахуванням агроекологічного стану грунтового покриву землекористування розроблено систему агроценозів. Базується вона на поєднанні природних фітоценозів із штучними. Штучні фітоценози передбачено на перезво- ложених та заболочених ділянках земель, не придатних у ролі ріллі, та угіддях, виведених під консервацію шляхом залуження крутих схилів.

Під час формування травосуміші для залуження схилів вивчено агроекологічний стан кожного грунтового контуру за рівнем його еродованості та крутизною схилу. Для залуження схилів розроблено травосуміш, у складі якої переважають злакові рослини (75 \%) (табл.). Їх розгалужена коренева система та густа надземна маса $з$ добре розвиненими прикореневими листами здатна ефективно захищати грунт від змиву впродовж майже 10 років. Види злакових трав підібрано таким чином, щоб їх травостій міг постійно виконувати захисну функцію і мав високу кормову якість, а також залишався високопродуктивним у несприятливі за кліматичними умовами роки. При цьому враховували, що костриця лучна, костриця червона, тонконіг лучний добре захищають грунт від ерозії, довго тримаються у травостої (8 років) та $є$ добрий кормом для тварин. Для отримання грунтозахисного ефекту рано навесні до суміші додають лисохвіст лучний та райграс високий, які тримаються у травостої близько 9 років. У підборі бобових трав враховували їх урожайність на сірих опідзолених грунтах у помірних кліматичних умовах. Зважаючи на це у суміші підібрано конюшину, люцерну, еспарцет і лядвенець. Вони істотно відрізняються за біологічними властивостями, що сприяє створенню стійкого, в будьяких умовах, високопродуктивного травостою. Особливу увагу під час підбору видів трав приділяли злаковим рослинам, оскільки більшість їх представників переносить загущення і здатна створювати довготермінові ценози. За винятком стоколосу безостого, злакові трави не самозріджуються та не мають негативного впливу на інші рослини (Panova, 1978).

Табл. Види трав для залуження крутих схилів із сірими опідзоленими грунтами та створення сіножаті на глейових грунтах

\begin{tabular}{|c|c|}
\hline \multicolumn{2}{|c|}{ Вид рослин } \\
\hline для залуження схилів & для створення сіножаті \\
\hline $\begin{array}{l}\text { Костриця лучна (Festuka pra- } \\
\text { tensis) }\end{array}$ & Лисохвіст лучний (Alopecu- \\
rus pretenses)
\end{tabular}

В основу формування травосуміші для перезволожених грунтів покладено відношення рослин до тривалого затоплення, яке часто спостерігається на глейових грунтах навесні. Враховано також те, що в посушливі роки урожайність травостою формується завдяки люцерні та тимофіївці (Viliams, 1949), а за умов довготривалого затоплення території - лисохвосту лучному, мітлиці білій. Менш стійкими у цьому сенсі $є$ костриця лучна, тонконіг лучний, конюшина лучна, люцерна жовта. 3 огляду на це питома вага бобових трав у сумішах змінюється на перезволожених грунтах досліджуваної в 
межах 10-15 \%. У сприятливі роки продуктивність визначатимуть трави, вибагливіші до умов зростання (конюшина, костриця). Загалом під час формування видового складу травостою зважали на те, що малокомпонентні травосуміші зменшують свою продуктивність та їх видовий склад збіднюється впродовж 4-6 років.

Висновки. Отже, запропонований підбір трав через видову насиченість рослинами з різними біологічними особливостями та вимогами до умов вирощування забезпечує стійкість фітоценозу в будь-яких кліматичних умовах та довше його продуктивне функціонування.

На основі зіставлення властивостей грунтового покриву i біологічних особливостей багаторічних трав встановлено, що для сірих та ясно-сірих опідзолених грунтів досліджуваного агроландшафту найпридатнішою $є$ травосуміш, в якій питома вага багаторічних трав для залуження схилів становить: бобових $-25 \%$ злакових $-75 \%$. Для створення сіножаті на глейових грунтах відповідно - 15 і $85 \%$.

\section{Перелік використаних джерел}

Chaplin-Kramer, R., Sim, S., \& Hamel, P. (2017). Life cycle assessment needs predictive spatial modelling for biodiversity and ecosystem services. Nature communications, 8, 150-165. https://doi.org/10.1038/ncomms15065

Durand, M.-H., Desilles, A., \& Saint-Pierre, P. (2017). Agroecological transition: A viability model to assess soil restoration. Natural

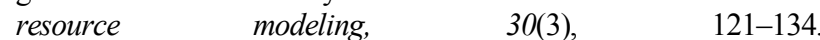
https://doi.org/10.1111/nrm.12134

Geijzendorffer, I. R., Cohen-Shacham, E., \& Cord, A. F. (2017) Ecosystem services in global sustainability policies. Environmental science, \& policy, $\quad$ \& $40-48$. https://doi.org/10.1016/j.envsci.2017.04.017

Gomez, J. A., Campos, M., \& Guzman, G. (2016). Soil erosion control, plant diversity, and arthropod communities under heterogeneous cover crops in an olive orchard. International Conference on Conservation Agriculture and Sustainable Land Use (CASLU). Budapest, Hungary. Environmental science and pollution research, 25(2), 977-989. https://doi.org/10.1007/s11356-016-8339-9

Lima, F. W., Enoch, J., de Gois, A. F., \& Avelar, C. T. (2017). Development of a spatially explicit approach for mapping ecosystem services in the Brazilian Savanna - MapES. Ecological indicators, 82, 513-525. https://doi.org/10.1016/j.ecolind.2017.07.028

Lohbeck, M., Winowiecki, L., \& Aynekulu, P. (2018). Ermias Traitbased approaches for guiding the restoration of degraded agricultural landscapes in East Africa. Journal of applied ecology, 55(1), 59-68. https://doi.org/10.1111/1365-2664.13017

Meadows, J., Herbohn, J., \& Emtage, N. (2018). Forest recovery in an Australian amenity landscape: implications for biodiversity conservation on small-acreage properties. Biodiversity and conservation, 27(1), 69-90. https://doi.org/10.1007/s10531-017-1422-9

Nanni, A. S., \& Grau, H. R. (2017). Land-Use Redistribution Compensated for Ecosystem Service Losses Derived from Agriculture Expansion. With Mixed Effects on Biodiversity in a NW Argentina Watershed. Forests, 8(8), 303-305. https://doi.org/10.3390/f8080303

Panova, L. S. (1978). Alelopaticheskaia aktivnost rastenii v stepnykh fitotcenozakh zapovednika Kamennye mogily. Problemy allelopatii: sb. nauchn. tr., (pp. 120-124). Kyiv: Nauk. dumka. [In Russian].

Sharashova, V. S. (1989). Ustoichivost pastbishhnykh ekosistem. Moscow: Agropromizdat. 238 p. [In Russian].

Sidibe, Yo., Foudi, S., \& Pascual, U. (2018). Adaptation to Climate Change in Rainfed Agriculture in the Global South: Soil Biodiversity as Natural Insurance. Ecological economics, 146, 588596. https://doi.org/10.1016/j.ecolecon.2017.12.017

Tarariko, O. H., \& Moskalenko, V. M. (Eds.). (2002). Kataloh zakhodiv z optymizatsii struktury ahrolandshaftiv ta zakhystu zemel vid erozii. Kyiv: Fitosotsiotsentr. 62 p. [In Ukrainian].

Toderi, M., Francioni, Ma., \& Seddaiu, G. (2017). Bottom-up design process of agri-environmental measures at a landscape scale: Evidence from case studies on biodiversity conservation and water protection. Land use policy, 68, 295-305. https://doi.org/10.1016/j.landusepol.2017.08.002

Varela, E., Verheyen, K., \& Valdes, A. (2018). Promoting biodiversity values of small forest patches in agricultural landscapes: Ecological drivers and social demand. Science of the total environment, 619, 1319-1329. https://doi.org/10.1016/j.scitotenv.2017.11.190

Viliams, V. R. (1949). Sobranie sochinenii, (Vol. 4). Moscow: Gosudarstvennoe izdatelstvo selskokhoziaistvennoi literatury. 502 p. [In Russian].

Wei, C., Behzad, A. O., \& Yakai, L. (2018). Studying early stage slope protection effects of vegetation communities for Xinnan Highway in China. Ecological engineering, 110, 87-98. https://doi.org/10.1016/j.ecoleng.2017.08.033

Wolz, K. J., Lovell, S. T., \& Branham, B. E. (2018). Frontiers in alley cropping: Transformative solutions for temperate agriculture. Global change biology, 24(3), 883-894. https://doi.org/10.1111/gcb.13986

Xutong, W., Shuai, W., \& Bojie, F. (2018). Land use optimization based on ecosystem service assessment: A case study in the Yanhe watershed. Land use policy. 72, 303-312. https://doi.org/10.1016/j.landusepol.2018.01.003

Yingiie, L., Liwei, Z., \& Junping, Ya. (2017). Mapping the hotspots and coldspots of ecosystem services in conservation priority setting. Journal of geographical sciences, 27(6), 681-696. https://doi.org/10.1007/s11442-017-1400-x

О. В. Дребот, А. П. Кудрик, А. О. Пищиль, О. П. Лукьяненко Житомирский начиональный агроэкологический университет, г. Житомир, Украина

\section{ПОВЫШЕНИЕ БИОРАЗНООБРАЗИЯ РАСТИТЕЛЬНЫХ ФОРМАЦИЙ ПРИ ЗЕМЛЕУСТРОЙСТВЕ АГРОЛАНДШАФТОВ}

\footnotetext{
Проанализированы современные мировые литературные источники, освещающие вопросы повышения биоразнообразия агроландшафтов. Установлено, что вопрос является актуальным, поскольку поддержание разнообразия видов живых элементов экосистемы является обязательным при формировании устойчивых территорий. Сделан вывод, что мировые исследования доказывают - восстановление устойчивости агроэкосистем путем уменьшения распаханности территории и увеличения биоразнообразия ведет к смягчению последствий изменения климата путем создания агроландшафтов, близких к естественным. Исследования проведены на площади землепользования в пределах Великохайчанского сельского совета Овручского района Житомирской области, расположенного на территории Словечанско-Овручского кряжа. Установлено, что рельеф, почвенный покров и характер переувлажнения исследуемой территории разнообразны. При формировании травосмесей для залужения склонов учтена степень эродированности почв и биологические особенности растений. При обустройстве сенокосов учтена чувствительность растений к росту на переувлажненных или заболоченных территориях. На основе сопоставления агроэкологических свойств почвенного покрова и биологических особенностей многолетних трав установлено, что для серых и ясно-серых оподзоленных почв исследуемого агроландшафта наиболее подходящей является травосмесь, в которой удельный вес многолетних трав для залужения склонов составляет: бобовых - 25 \%, злаковых - 75 \%. Для создания сенокосов на глеевых почвах соответственно - 15 и $85 \%$.
}

Ключевые слова: землеустройство; сельскохозяйственные угодья; биоразнообразие; залужение склонов; травосмеси. 
O. V. Drebot, A. P. Kudryk, O. V. Pitsil, O. P. Lukianenko

Zhytomyr National Agroecological University, Zhytomyr, Ukraine

\section{INCREASING PLANT FORMATION BIODIVERSITY DURING AGRICULTURAL LANDSCAPE MANAGEMENT}

The authors analyse current international literary sources addressing the issues of increasing biodiversity. We have found that restoring agricultural ecosystem stability by means of reducing plough disturbance in the area and increasing biodiversity results in climate change mitigation by creating agricultural landscapes that are similar to natural landscapes. The studies have been conducted within land use area located within the jurisdiction of Velyka Khaicha Village Council in Ovruch District, Zhytomyr Oblast, which lies on the Slovechansk-Ovruch Ridge. The studied area varies in its relief, topsoil and waterlogging level. The land use area contains slopes ranging from $3^{\circ}$ to $11^{\circ}$. Grey forest soils affected by varying degrees of erosion predominate on the area with a complex relief, whereas deluvial sediments, calcareous gley and soddy low-podzol gley soils prevail in waterlogged areas. Eroded land area equals 765.7 ha, while waterlogged and boggy land area equals 365.8 ha. The agroecological state of the topsoil in the studied area has been analysed in terms of soil erosion class and waterlogging intensity. Soil erosion class and certain biological properties of plant species, such as root system branching, projected soil surface coverage by plant tops, as well as spring regrowth times, have been taken into account when developing grass mixtures for grassland restoration on slopes. Plant sensitivity to growing in waterlogged or boggy areas has been taken into account during hay meadow management. The allelopathic properties of plant species have also been taken into account when forming plant aggregations. A grass mixture consisting primarily of such gramineous plants as Festuka pratensis, Poa pratensis, Dactylis glomerata, Loliym perrene, as well as such leguminous plants as Trifolium pratensis, Medicago media, Onobrychis arenaria, Gotus corhiculatus, has been developed for grassland restoration on slopes. The ratio of gramineous plants in the grass mixture for hay meadow management is even higher; leguminous plants in this grass mixture include Trifolium pratensis and Medicago falkata. Through a comparison of agroecological properties of the topsoil and biological properties of perennial plants it has been established that the ratio of perennial plant species for grassland restoration on slopes in the optimal grass mixture for grey and light-grey podzolised soils within the studied agricultural landscape equals $25 \%$ of leguminous plants and $75 \%$ of gramineous plants, and in the grass mixture for hay meadow creation on gley soils, $15 \%$ and $85 \%$, respectively.

Keywords: land management; agricultural land; biodiversity; grassland restoration on slopes; grass mixtures. 